\title{
Wolność gospodarcza a postępy w transformacji gospodarczej krajów WNP w latach 2000-2014
}

Daria Pilarczyk

\section{Wstęp}

Wspólnota Niepodległych Państw (WNP) to międzynarodowa organizacja powołana w 1991 r. mająca na celu zrzeszenie krajów byłego Związku Radzieckiego. Obecnie do organizacji (grudzień 2018 r.) należą: Azerbejdżan, Armenia, Białoruś, Kazachstan, Kirgistan, Mołdawia, Rosja, Tadżykistan i Uzbekistan. Ukraina, choć zaliczana do krajów-założycieli WNP, nigdy nie podpisała karty WNP, więc oficjalnie nie była członkiem organizacji. W maju 2018 r. prezydent Ukrainy poinformował o całkowitej rezygnacji z członkostwa w WNP. Do 2005 r. do WNP zaliczany był Turkmenistan, obecnie posiadający tytuł obserwatora, a w latach 1993-2009 do WNP należała także Gruzja (CIS STAT).

W niniejszym opracowaniu jako kraje WNP zostały potraktowane te, które przez cały okres badawczy (lata 2000-2014) były de facto jej członkami, dlatego też wszystkie analizy będą obejmować dziesięć krajów: Azerbejdżan, Armenię, Białoruś, Kazachstan, Kirgistan, Mołdawię, Rosję, Tadżykistan, Ukrainę i Uzbekistan.

Celem opracowania będzie zbadanie za pomocą współczynnika korelacji liniowej Pearsona współzależności między wolnością gospodarczą a zmianami mającymi na celu wprowadzenie gospodarki wolnorynkowej w krajach zaliczanych do Wspólnoty Niepodległych Państw. Za okres badawczy przyjęto lata 2000-2014. Zakończenie analizy na 2014 r. związane jest ze zmienieniem przez Europejski Bank Odbudowy i Rozwoju metodologii oceny postępów transformacji gospodarczej - uwzględnienie późniejszych danych nie dałoby ich pełnej porównywalności.

\footnotetext{
* Daria Pilarczyk - magister, Uniwersytet w Białymstoku, Wydział Ekonomii i Zarządzania, Katedra Polityki Ekonomicznej i Rozwoju Gospodarczego, dariadonatapilarczyk@gmail.com.
} 


\section{Proces transformacji jako podstawa wolności gospodarczej}

W literaturze transformacja gospodarcza ukazywana jest jako przejście od gospodarki centralnie planowanej do wolnorynkowej. Transformacja gospodarcza wraz z transformacją ustrojową, obejmującą aspekt polityczny, składają się na transformację systemową (Nasilowski 1995, s. 17). Za istotę transformacji gospodarczej można więc uznać „zastąpienie własności państwowej (socjalistycznej) własnością prywatną (kapitalistyczną), a regulacji administracyjnej (centralnego planowania) - regulacją rynkową" (Bałtowski, Miszewski 2006, s. 23).

Bezpośrednią przyczyną zmuszającą kraje Europy Środkowo-Wschodniej do transformacji systemowej był upadek Związku Radzieckiego w 1991 r. W niektórych z tych krajów procesy te rozpoczęły się jednak znacznie wcześniej i - jak podkreśla się w wielu opracowaniach - to nie zjawiska polityczne, tylko ekonomiczne doprowadziły do rozpadu systemu komunistycznego. Gospodarce nakazowo-rozdzielczej brakowało bowiem uwarunkowań ekonomicznych i instytucjonalnych niezbędnych do zwiększania jej efektywności, co przekładało się na ograniczenia w rozwoju społecznym i gospodarczym krajów bloku wschodniego (Maksimczuk 2013, s. 66).

Według L. Balcerowicza na transformację składają się następujące elementy (Balcerowicz 1997, s. 179):

1. stabilizacja $\mathrm{w}$ aspekcie makroekonomicznym;

2. liberalizacja mająca na celu zlikwidowanie ograniczeń w prowadzeniu działalności gospodarczej;

3. przebudowa instytucjonalna, której celem jest stworzenie nowych ram funkcjonowania gospodarki i państwa.

Jedną z głównych cech gospodarki rynkowej - oprócz dominacji własności prywatnej, braku ograniczeń w przekazywaniu praw własności, funkcjonowaniu instytucji związanych z rynkiem i integralności rynku - jest wolność gospodarcza (Milewski 2007, s. 90). Nie ulega więc wątpliwości, że rozszerzanie wolności gospodarczej powinno iść w parze z postępami w transformacji gospodarczej, która jest procesem prowadzącym do utworzenia gospodarki rynkowej.

W najprostszym ujęciu wolność gospodarczą definiuje się jako prawo do prowadzenia działalności gospodarczej i decydowania o swojej własności. W literaturze wskazuje się, że o „wolności gospodarczej jednostek można mówić, gdy własność, w posiadanie której [jednostki] weszły bez użycia siły, oszustwa czy kradzieży, jest chroniona przed działaniem innych osób oraz gdy jednostki te mogą swobodnie ją wykorzystywać, wymieniać lub przekazywać innym, nie naruszając przy tym identycznych praw innych jednostek" (Gwartney, Lawson, Block 1996, s. 12).

$\mathrm{Na}$ wolność gospodarczą składają się dwa elementy: wolność od ingerencji państwa w obszarze działalności gospodarczej oraz prawo do wolnej i równej 
konkurencji (Pawłowicz 1993, s. 70). Złożoność tego zagadnienia powoduje, że nie istnieje miernik pozwalający na jednoznaczną ocenę poziomu wolności gospodarczej i zazwyczaj rozpatruje się ją, uwzględniając kilka aspektów.

\section{Wolność gospodarcza w krajach WNP w latach 2000-2014}

Wskaźnik Wolności Gospodarczej (Index of Economic Freedom, IEF) opracowywany jest od 1995 r. przez Heritage Foundation. Przyjmuje on wartości od 0 do 100 , a im wyższa wartość, tym lepsza jest sytuacja w zakresie swobody gospodarczej.

Wskaźnik Wolności Gospodarczej dzieli się na szereg subwskaźników, punktowanych od 0 do 100 . W okresie 2000-2014 w ramach IEF oceniano (Heritage Foundation):

1. prawa własności;

2. praworządność;

3. obciążenia podatkowe;

4. wydatki rządowe;

5. wolność biznesu;

6. wolność pracy (subwskaźnik wprowadzony od 2005 r.);

7. wolność monetarną;

8. wolność handlu;

9. wolność inwestycji;

10. wolność finansową.

Wymienione subwskaźniki można podzielić na cztery grupy składające się na wolność gospodarczą. Należą do nich: przestrzeganie prawa (prawa własności i praworządność), interwencja rządu (obciążenia podatkowe, wydatki rządowe), skuteczność regulacji (wolność biznesu, wolność pracy, wolność monetarna) oraz otwartość rynku (wolność handlu, wolność inwestycji, wolność finansowa). Ogólna wartość Wskaźnika Wolności Gospodarczej obliczana jest na podstawie wartości równorzędnych subwskaźników.

Najwyższą wartość Wskaźnika Wolności Gospodarczej w 2000 r. wśród krajów WNP zanotowano w Armenii (63 pkt) (tabela 1). Na drugim miejscu uplasowała się Mołdawia (59,6 pkt), a na trzecim Kirgistan (55,7 pkt). Najsłabiej w danym roku wypadał Uzbekistan ze Wskaźnikiem Wolności Gospodarczej na poziomie 38,1 pkt. Wynikało to ze stosunkowo niskiej punktacji przyznanej za takie obszary jak praworządność (10 pkt), wolność finansowa (10 pkt), prawa własności (30 pkt) czy wolność inwestycji (30 pkt).

W większości analizowanych krajów do 2014 r. można było zauważyć tendencję wzrostową wartości omawianego wskaźnika. Wyjątek stanowiła Mołdawia, gdzie w 2014 r. był on o 2,3 pkt niższy niż w 2000 r. 


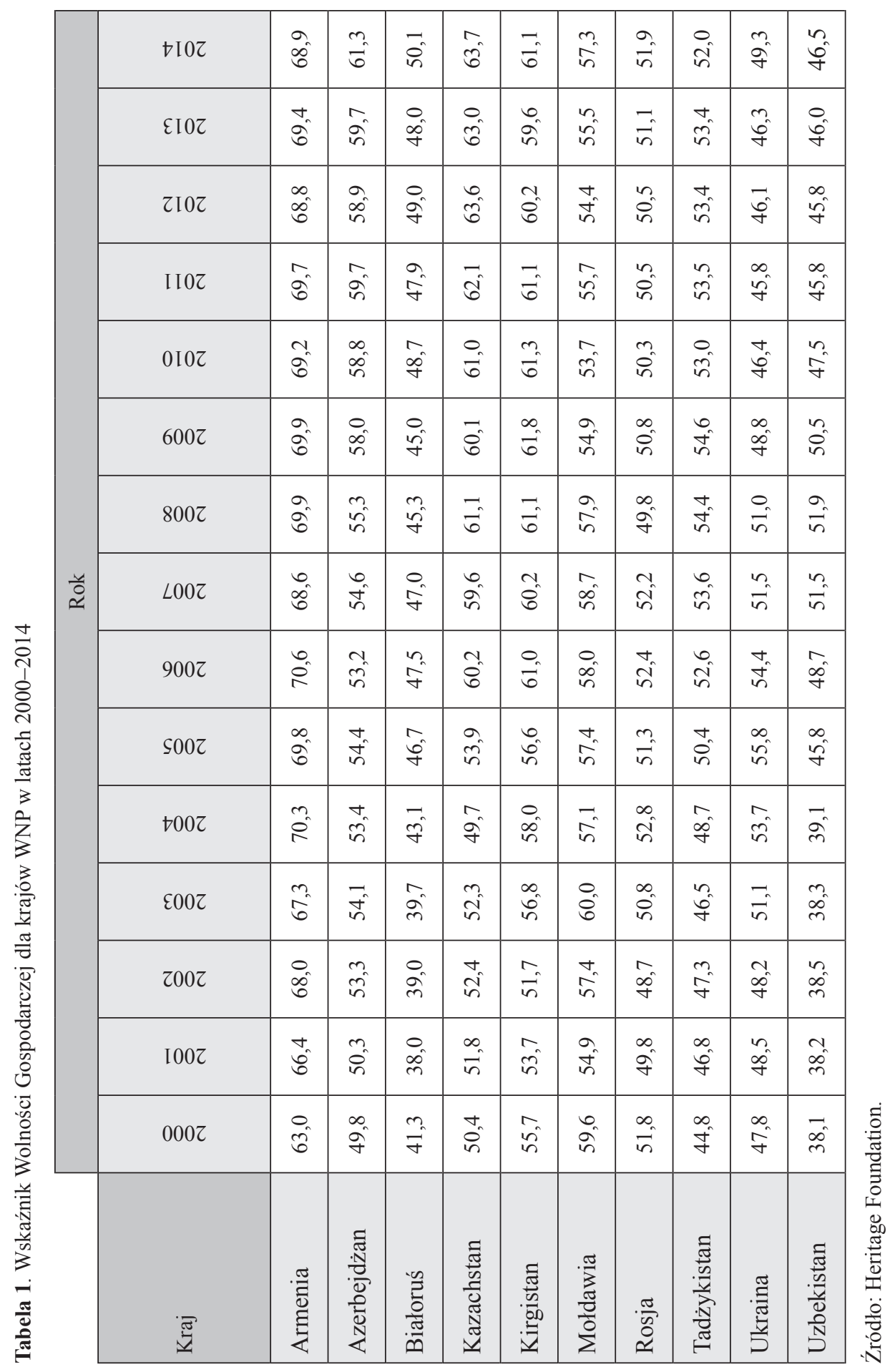


Największe postępy w zakresie wolności gospodarczej w latach 2000-2014 nastąpiły w Kazachstanie (z 50,4 pkt do 63,7 pkt, czyli o ponad 13 pkt) oraz w Azerbejdżanie (z 49,8 pkt do 61,3 pkt, czyli o 11,5 pkt). Pozytywne zmiany zaszły także na Białorusi (wzrost o 8,8 pkt w 2014 r. w porównaniu z rokiem 2000) i w Uzbekistanie (wzrost o 8,4 pkt).

Dużym wahaniom podlegały wartości Wskaźnika Wolności Gospodarczej na Ukrainie. W $2000 \mathrm{r}$. wynosił on 47,8 pkt i do 2005 r. osiągnął poziom 55,8 pkt. Od 2006 r. widoczne były niekorzystne zmiany w tym zakresie i w 2011 r. Wskaźnik Wolności Gospodarczej był równy 45,8 pkt (będący wartością minimalną dla Ukrainy w latach 2000-2014). Wynikało to głównie ze zmniejszenia wartości takich subwskaźników jak: wydatki rządowe, wolność biznesu, wolność inwestycji oraz wolność finansowa. W 2014 r. Wskaźnik Wolności Gospodarczej na Ukrainie był o 1,5 pkt wyższy niż w $2000 \mathrm{r}$.

Tendencja spadkowa wartości Wskaźnika Wolności Gospodarczej wystąpiła w niektórych analizowanych krajach w latach 2008-2009. Było to następstwem światowej recesji, która wymusiła na władzach tych państw wprowadzenie pewnych ograniczeń w ramach działań antykryzysowych.

\section{Przebieg transformacji gospodarczej w krajach WNP w latach 2000-2014}

Europejski Bank Odbudowy i Rozwoju (EBOR) to międzynarodowa instytucja, która rozpoczęła działalność w 1991 r. Jako główny cel jej powołania wskazuje się pomoc krajom Europy Centralnej i Wschodniej w procesie transformacji z gospodarki centralnie planowanej do wolnorynkowej (Timeline...). Od $1994 \mathrm{r}$. EBOR monitoruje i ocenia postępy krajów transformujących się, wykorzystując w tym celu kilka wskaźników. Przyznawane oceny obejmują cztery główne elementy gospodarki rynkowej: przedsiębiorstwa, rynki i handel, instytucje finansowe oraz infrastrukturę.

W przypadku reform przedsiębiorstw bierze się pod uwagę następujące wskaźniki: małą prywatyzację, dużą prywatyzację oraz restrukturyzację przedsiębiorstw. Pierwszy z nich obejmuje analizę zmian własnościowych małych przedsiębiorstw, a drugi monitoruje zmiany własności średnich i dużych przedsiębiorstw. Za pomocą wskaźnika restrukturyzacji ocenia się zmiany w zakresie subsydiowania i dotowania przedsiębiorstw przez władze państwowe oraz wprowadzania skutecznych procedur upadłościowych. Reformę rynków i handlu mierzy się, analizując liberalizację cen, handlu i rynku walutowego oraz konkurencyjność, czyli skuteczność polityki w zakresie zwalczania nadużyć na rynku i praktyk ograniczających nielegalną konkurencję. W kategorii ,instytucje bankowe" ocenia się rozwój sektora bankowego oraz tworzenie rynków papierów wartościowych i pozabankowych instytucji finansowych. Do mierzenia 
reform w zakresie infrastruktury stosuje się złożoną ocenę postępów w następujących obszarach: telekomunikacji, energii elektrycznej, kolei, dróg oraz wody i ścieków.

EBOR przyznaje oceny od 1 do 4+, przy czym 1 oznacza brak zmiany lub niewielką zmianę w stosunku do gospodarki centralnie planowanej, a 4+ jest jednoznaczne z osiągnięciem poziomu charakterystycznego dla gospodarki wolnorynkowej. Na potrzeby analizy ocena ze znakiem ,,+" została powiększona o 0,3, a ocenę ze znakiem „,-" pomniejszono o 0,3. Przykładowo, ocenę $3+$ zamieniono na 3,3, a ocenę $3-$ na 2,7. Dlatego też minimalną oceną przyznaną krajowi może być 1,0 , a maksymalną 4,3 .

Dla omówionych kategorii wyliczono średnią arytmetyczną przyznanych ocen, co pozwala na przeanalizowanie zmian transformacji gospodarczej w krajach WNP w latach 2000-2014.

W 2000 r. najwyższą średnią wyników w kategorii „,przedsiębiorstwa” wśród krajów WNP odnotowano w Rosji $(3,1)$ (tabela 2). Zbliżone wartości występowały także w Kazachstanie $(3,0)$ oraz w Kirgistanie $(3,0)$. Najgorzej w danej kategorii w 2000 r. wypadła Białoruś $(1,3)$, która nie przeprowadziła reform w zakresie prywatyzacji średnich i dużych przedsiębiorstw oraz restrukturyzacji podmiotów gospodarczych.

W Kazachstanie nie odnotowano żadnych zmian wartości średniej w latach 2000-2014, a w Azerbejdżanie - w latach 2003-2014. Sytuacja w Rosji pogorszyła się, a średnia wskaźników zmniejszyła się z 3,2 w 2004 r. do 3,1 w 2005 r. i utrzymywała się na tym samym poziomie do $2014 \mathrm{r}$.

Warto podkreślić, że prywatyzacja małych przedsiębiorstw w państwach zaliczanych do WNP przebiegała znacznie szybciej niż średnich i dużych. W 2014 r. siedem z dziesięciu analizowanych krajów osiągnęło ocenę $4 \mathrm{w}$ przypadku małej prywatyzacji. Do wyjątków należały Azerbejdżan (4-), Uzbekistan (3+) oraz Białoruś $(2+)$.

W 2014 r. najwyższy wzrost średniej w porównaniu z rokiem 2000 w kategorii ,przedsiębiorstwa” wystąpił na Białorusi (z 1,3 w 2003 r. do 1,9 w 2014 r.), mimo to kraj ten nadal wypadał najgorzej w badanej grupie.

W kategorii „rynki i handel” w 2000 r. wśród krajów WNP najwyższą średnią zanotowano w Kirgistanie $(3,6)$, gdzie zakończono wówczas proces liberalizacji cen oraz handlu i rynku walutowego (oceny na poziomie 4+) (tabela 3). Najniższą średnią w 2000 r. odnotowano w Uzbekistanie $(1,9)$, co wynikało z przyznania stosunkowo niskich ocen za liberalizację handlu i rynku walutowego oraz wdrażania polityki w zakresie zwalczania nadużyć na rynku i praktyk ograniczających nielegalną konkurencję. 


\begin{tabular}{|c|c|c|c|c|c|c|c|c|c|c|c|}
\hline \multirow{15}{*}{$\frac{y}{2}$} & $\downarrow \mathrm{I} 0 \mathrm{Z}$ & $m$ & $\begin{array}{l}0 \\
i\end{array}$ & $\underline{\sigma}$ & $\stackrel{\circ}{m}$ & ñ & $\stackrel{\circ}{m}$ & $\vec{m}$ & $\stackrel{\infty}{i}$ & $\vec{m}$ & $\begin{array}{l}0 \\
i\end{array}$ \\
\hline & $\varepsilon \mathrm{I} 0 \tau$ & $m$ & $\begin{array}{l}0 \\
\text { i }\end{array}$ & $\underline{a}$ & $\stackrel{0}{m}$ & ñ & $\stackrel{\circ}{m}$ & $\vec{m}$ & $\stackrel{\infty}{i}$ & $\vec{m}$ & $\begin{array}{l}0 \\
i\end{array}$ \\
\hline & ZIOZ & $m$ & $\begin{array}{l}0 \\
\text { i }\end{array}$ & $\underline{a}$ & $\stackrel{\circ}{m}$ & r & $\stackrel{\circ}{m}$ & $\vec{m}$ & $\stackrel{\infty}{i}$ & $\vec{m}$ & $\begin{array}{l}0 \\
i\end{array}$ \\
\hline & I IOZ & $\hat{m}$ & $\begin{array}{l}0 \\
\text { i }\end{array}$ & $\underline{a}$ & $\stackrel{\circ}{m}$ & ñ & $\stackrel{0}{m}$ & $\vec{m}$ & $\stackrel{\infty}{i}$ & $\vec{m}$ & $\begin{array}{l}0 \\
i\end{array}$ \\
\hline & $0 \mathrm{I} 0 \mathrm{Z}$ & $m$ & $\begin{array}{l}0 \\
\text { i }\end{array}$ & 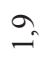 & $\stackrel{0}{m}$ & ñ & $\stackrel{0}{m}$ & $\vec{m}$ & $\stackrel{\infty}{i}$ & $\vec{m}$ & $\stackrel{0}{i}$ \\
\hline & $600 z$ & $\stackrel{m}{m}$ & $\begin{array}{l}0 \\
\text { i }\end{array}$ & $\stackrel{a}{a}$ & $\stackrel{\circ}{m}$ & $\stackrel{\sim}{m}$ & $\stackrel{\circ}{m}$ & $\vec{m}$ & $\stackrel{\infty}{i}$ & $\vec{m}$ & $\begin{array}{l}0 \\
i\end{array}$ \\
\hline & $800 z$ & $m$ & $\begin{array}{l}0 \\
\text { i }\end{array}$ & $\underline{\sigma}$ & $\stackrel{\circ}{m}$ & r & $\stackrel{\circ}{m}$ & $\vec{m}$ & $\vec{i}$ & $\stackrel{\circ}{\circ}$ & $\begin{array}{l}0 \\
i\end{array}$ \\
\hline & $\angle 00 Z$ & $\tilde{m}$ & $\begin{array}{l}0 \\
i\end{array}$ & $\stackrel{+}{\sigma}$ & $\stackrel{\circ}{m}$ & ñ & ते & $\vec{m}$ & $\hat{i}$ & $\stackrel{0}{m}$ & $\stackrel{6}{i}$ \\
\hline & $900 z$ & $\stackrel{m}{m}$ & $\begin{array}{l}0 \\
i\end{array}$ & $\stackrel{\nabla}{\rightarrow}$ & $\stackrel{0}{m}$ & $\stackrel{\sim}{n}$ & $\hat{\text { iे }}$ & $\vec{m}$ & $\hat{i}$ & $\stackrel{0}{m}$ & $\begin{array}{l}0 \\
i\end{array}$ \\
\hline & $\varsigma 00 Z$ & m & $\begin{array}{l}0 \\
\text { i }\end{array}$ & $\stackrel{\nabla_{n}}{\rightarrow}$ & $\stackrel{0}{m}$ & m & ते & $\vec{m}$ & $\hat{i}$ & $\stackrel{\circ}{m}$ & $\stackrel{+}{i}$ \\
\hline & t00z & $\stackrel{\sim}{m}$ & $\begin{array}{l}0 \\
\text { i }\end{array}$ & $\stackrel{\sigma_{a}}{\rightarrow}$ & $\stackrel{\circ}{m}$ & ñ & $\stackrel{\infty}{i}$ & m & $\stackrel{0}{i}$ & $\stackrel{0}{m}$ & $\stackrel{+}{i}$ \\
\hline & $\varepsilon 00 Z$ & $\vec{m}$ & $\begin{array}{l}0 \\
i\end{array}$ & $\stackrel{\nabla}{\sigma}$ & $\stackrel{\circ}{m}$ & $\stackrel{\circ}{\oplus}$ & $\stackrel{\infty}{i}$ & $\stackrel{\sim}{m}$ & $\begin{array}{l}0 \\
i\end{array}$ & $\stackrel{\circ}{m}$ & $\stackrel{+}{i}$ \\
\hline & zo0z & $\vec{m}$ & $\stackrel{+}{i}$ & $\stackrel{m}{\rightarrow}$ & $\stackrel{\circ}{m}$ & $\stackrel{0}{m}$ & $\vec{a}$ & rn & $\begin{array}{l}0 \\
i\end{array}$ & $\overrightarrow{\hat{i}}$ & $\stackrel{+}{i}$ \\
\hline & I00Z & ते & $\tilde{c}$ & $\stackrel{2}{-}$ & $\stackrel{\circ}{m}$ & $\stackrel{\circ}{m}$ & $\overrightarrow{\hat{i}}$ & $\stackrel{r}{m}$ & $\begin{array}{l}0 \\
i\end{array}$ & $\stackrel{\infty}{i}$ & $\stackrel{+}{i}$ \\
\hline & $000 z$ & $\stackrel{\infty}{i}$ & î & $\stackrel{m}{-}$ & $\stackrel{\circ}{\circ}$ & $\stackrel{0}{\circ}$ & $\hat{\mathrm{i}}$ & $\vec{m}$ & $\stackrel{\nabla}{i}$ & $\hat{i}$ & $\stackrel{\nabla}{i}$ \\
\hline & 䨔 & $\frac{\cdot \frac{\pi}{Z}}{\stackrel{\Xi}{ \pm}}$ & 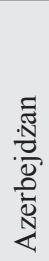 & $\frac{\mathscr{n}}{\frac{\pi}{0}}$ & 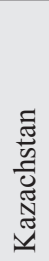 & 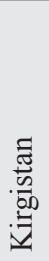 & $\frac{\frac{\pi}{3}}{\frac{\pi}{0}}$ & $\frac{\pi}{\tilde{0}}$ & 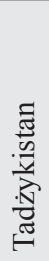 & & 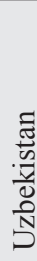 \\
\hline
\end{tabular}




\begin{tabular}{|c|c|c|c|c|c|c|c|c|c|c|c|}
\hline \multirow{15}{*}{ थै } & tI0Z & $\begin{array}{l}0 \\
\text { m }\end{array}$ & ñ & $\stackrel{\nabla}{i}$ & $\vec{m}$ & $\stackrel{0}{\oplus}$ & $\stackrel{0}{m}$ & $\stackrel{\nabla}{\dot{m}}$ & $\vec{m}$ & $\stackrel{\dot{m}^{\prime}}{ }$ & $\stackrel{\circ}{i}$ \\
\hline & $\varepsilon \mathrm{I} 0 \tau$ & $\stackrel{0}{\oplus}$ & $\stackrel{\sim}{m}$ & $\stackrel{+}{i}$ & $\vec{m}$ & $\stackrel{0}{\oplus}$ & $\stackrel{0}{m}$ & $\stackrel{0}{\oplus}$ & $\vec{m}$ & $\stackrel{\sigma^{2}}{m}$ & $\stackrel{\circ}{i}$ \\
\hline & ZI0Z & $\stackrel{0}{m}$ & m & $\stackrel{\nabla}{i}$ & $\vec{m}$ & $\stackrel{0}{m}$ & $\stackrel{0}{m}$ & $\stackrel{0}{m}$ & $\stackrel{\circ}{m}$ & $\stackrel{+}{m}$ & $\stackrel{\circ}{i}$ \\
\hline & I IOZ & $\stackrel{0}{m}$ & r & $\hat{n}$ & $\vec{m}$ & $\stackrel{0}{\oplus}$ & $\stackrel{0}{m}$ & $\stackrel{m}{m}$ & $\stackrel{\circ}{m}$ & $\stackrel{+}{r}$ & $\stackrel{\circ}{i}$ \\
\hline & $0 \mathrm{I} 0 \mathrm{Z}$ & $\hat{n}$ & $m$ & $\begin{array}{l}0 \\
i\end{array}$ & $\stackrel{\sim}{m}$ & $\stackrel{0}{\oplus}$ & $\stackrel{0}{m}$ & r & $\stackrel{\circ}{m}$ & $\stackrel{\sigma_{m}}{m}$ & $\vec{i}$ \\
\hline & $600 z$ & $\hat{n}$ & $\stackrel{m}{m}$ & $\stackrel{\vec{d}}{\mathrm{~d}}$ & $\stackrel{r}{n}$ & $\stackrel{0}{m}$ & $\stackrel{0}{m}$ & ñ & $\overrightarrow{\hat{\imath}}$ & $\stackrel{\sigma_{n}}{m}$ & $\vec{i}$ \\
\hline & $800 z$ & $\hat{m}$ & $m$ & $\stackrel{\text { â }}{i}$ & mु & $\stackrel{0}{m}$ & $\stackrel{0}{m}$ & ñ & $\hat{\mathrm{i}}$ & $\stackrel{0}{m}$ & $\overrightarrow{\mathrm{i}}$ \\
\hline & $\angle 00 Z$ & $\hat{m}$ & $\stackrel{m}{m}$ & $\hat{n}$ & ñ & $\stackrel{\sigma}{m}$ & $\stackrel{0}{m}$ & $\stackrel{\sim}{m}$ & $\hat{\vec{~}}$ & $\stackrel{m}{m}$ & $\vec{i}$ \\
\hline & $900 z$ & $\hat{n}$ & $\stackrel{m}{m}$ & $\stackrel{m}{i}$ & m & $\stackrel{\circ}{m}$ & $\dot{m}$ & ñ & $\vec{a}$ & $m$ & $\vec{i}$ \\
\hline & $\varsigma 00 乙$ & $\hat{m}$ & $m$ & $\stackrel{n}{i}$ & ñ & $\stackrel{0}{m}$ & $\stackrel{\nabla^{\prime}}{m}$ & r & ते & $m$ & $\vec{i}$ \\
\hline & t00z & $\stackrel{0}{m}$ & rn & $\stackrel{m}{i}$ & r & $\stackrel{\sigma}{m}$ & $m$ & m & $\hat{\text { ते }}$ & m & $\stackrel{0}{i}$ \\
\hline & $\varepsilon 00 Z$ & m. & m & $\stackrel{n}{d}$ & $\vec{m}$ & $\stackrel{\circ}{m}$ & $m$ & rn & $\hat{\text { ते }}$ & r & ㅇ \\
\hline & $z 00 z$ & $\stackrel{\nabla}{m}$ & nु & $\stackrel{m}{i}$ & $\vec{m}$ & $\stackrel{b}{m}$ & $\stackrel{m}{m}$ & $\vec{m}$ & $\vec{i}$ & ñ & $\overrightarrow{\mathrm{i}}$ \\
\hline & $\mathrm{I} 00 \mathrm{Z}$ & $\underset{m}{\dot{m}}$ & $\vec{m}$ & $\tilde{n}$ & $\vec{m}$ & $\begin{array}{l}0 \\
m\end{array}$ & $m^{2}$ & $\stackrel{\circ}{n}$ & ते & $\vec{m}$ & $\vec{i}$ \\
\hline & $000 z$ & $\vec{m}$ & $\vec{m}$ & $\stackrel{\circ}{i}$ & $\vec{m}$ & $\stackrel{0}{m}$ & m & $\hat{~}$ & $\stackrel{\circ}{m}$ & $\vec{m}$ & $\underline{-}$ \\
\hline & 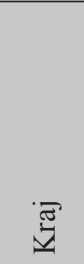 & $\begin{array}{l}\cdot \frac{\pi}{Z} \\
\frac{\Xi}{\Xi} \\
\frac{\Xi}{Z}\end{array}$ & 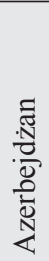 & $\frac{\sum_{0}^{0}}{\frac{0}{\pi}}$ & 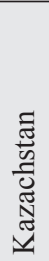 & 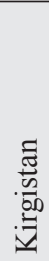 & $\begin{array}{l}\frac{\pi}{2} \\
\frac{\pi}{\frac{\pi}{0}} \\
\frac{0}{2}\end{array}$ & $\begin{array}{l}\frac{\pi}{2} \\
\frac{2}{2}\end{array}$ & 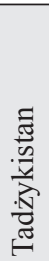 & $\begin{array}{l}\stackrel{\Xi}{\pi} \\
\frac{\pi}{5}\end{array}$ & 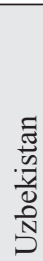 \\
\hline
\end{tabular}


Po 2003 r. doszło do niewielkiej poprawy średniej w większości badanych krajów. Warto zwrócić uwagę na przypadek Rosji, gdzie w latach 2012-2013 średnia w tej kategorii wyniosła 3,6. W 2014 r. zmniejszyła się ona do 3,4, co było związane ze zmniejszeniem oceny dotyczącej liberalizacji handlu i rynku walutowego (z 4 do 4-). Wynikało to z odpowiedzi Rosji na sankcje krajów zachodnich nałożone w wyniku kryzysu na Ukrainie. Władze rosyjskie w sierpniu 2014 r. wprowadziły zakaz importowania towarów żywnościowych pochodzących z krajów Unii Europejskiej oraz Ukrainy.

W 2014 r. Mołdawia, podobnie jak Armenia i Kirgistan, uzyskała średnią w kategorii „rynki i handel” na poziomie 3,6. Najniżej uplasował się ponownie Uzbekistan, w którym w porównaniu z rokiem 2003 nie zaszły żadne zmiany w tym zakresie. Należy zaznaczyć, że w 2014 r. żaden kraj nie uzyskał średniej równej 4 lub więcej.

Wskazuje się, że na początku XXI w. doszło do wyraźnego spowolnienia transformacji gospodarczej, którego przyczyna tkwiła w tym, że w większości krajów reformy pierwszej fazy (mała prywatyzacja, liberalizacja cen i handlu) już się wtedy zakończyły lub osiągnęły poziom zbliżony do poziomu gospodarki wolnorynkowej. Wyjątkami były Białoruś i Uzbekistan, które wypadały znacznie gorzej na tle pozostałych państw pod względem uzyskiwanych ocen.

Wykres 1. Wskaźniki EBOR w kategorii „instytucje finansowe” dla krajów WNP w 2000 r. i 2010 r.

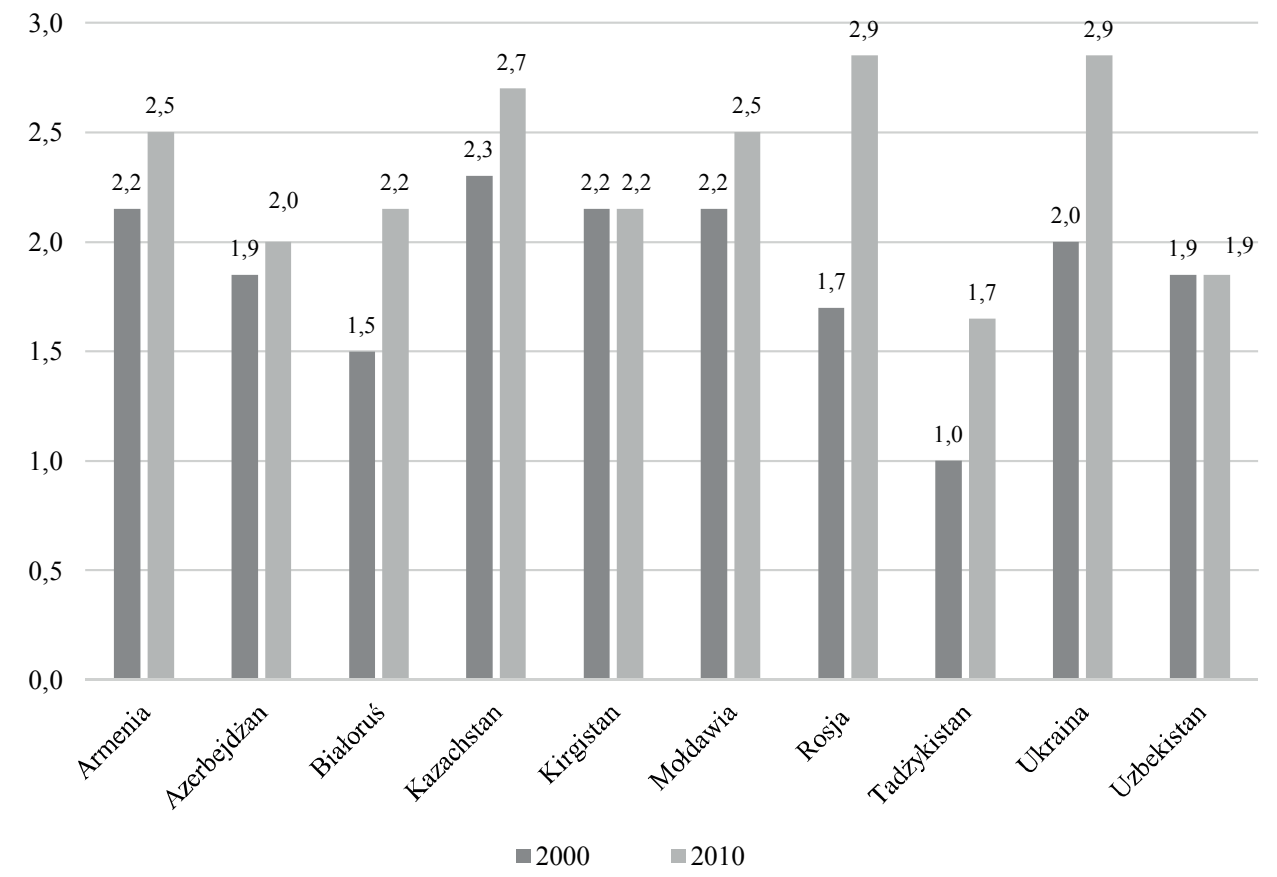

Źródło: Heritage Foundation. 
W 2000 r. najwyższą średnią w zakresie instytucji finansowych zanotowano w Kazachstanie $(2,3)$ (wykres 1). Wyraźny brak postępów w zakresie tworzenia i restrukturyzacji instytucji finansowych w latach 2000-2010 można zauważyć w Kirgistanie oraz Uzbekistanie. Najgorsza - na tle badanych krajów - sytuacja była w Tadżykistanie, gdzie w 2000 r. średnia wynosiła 1, a w 2010 r. $-1,7$. W 2010 r. w dwóch państwach średnia była najwyższa i osiągnęła 2,9 - w Rosji i na Ukrainie. Warto jednak zwrócić uwagę na to, że zarówno w 2000 r., jak i 2010 r. wartość średniej arytmetycznej w kategorii ,instytucje finansowe” nie wyniosła 3 w żadnym kraju.

Niewielkie zmiany w latach 2002-2010 dotyczyły także postępów w zakresie infrastruktury (wykres 2). W 2002 r. najniższe oceny w takich obszarach jak telekomunikacja, energia elektryczna, koleje, drogi oraz woda i ścieki otrzymały Białoruś, Kirgistan i Tadżykistan, co poskutkowało ich średnimi wartościami na poziomie 1,3. W przypadku Białorusi sytuacja nie zmieniła się aż do $2010 \mathrm{r}$.

Wykres 2. Wskaźniki EBOR w kategorii „,infrastruktura” dla krajów WNP w 2002 r. oraz 2010 r.

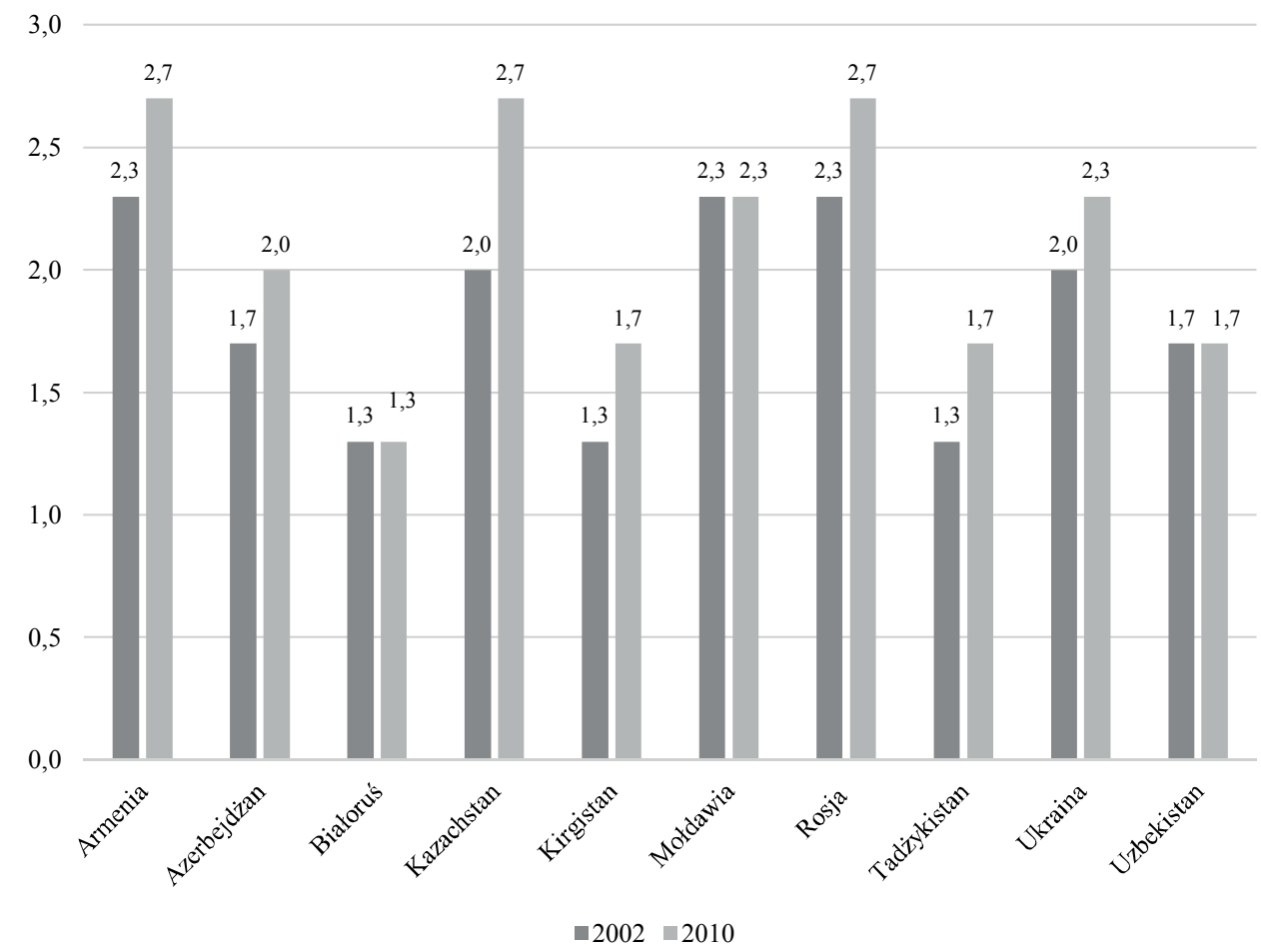

Źródło: Heritage Foundation.

Mimo stosunkowo niskiej średniej Kirgistanu, kraj ten rozpoczął duże reformy telekomunikacyjne. W 2003 r. całkowicie zliberalizowano kirgiski rynek 
telekomunikacyjny, co było zgodne z porozumieniem podpisanym przez ten kraj ze Światową Organizacją Handlu. W 2010 r. najwyższe średnie w tej kategorii odnotowano w Armenii, Kazachstanie oraz Rosji (we wszystkich trzech przypadkach równe 2,7).

\section{Analiza współzależności między wolnością gospodarczą a postępami w transformacji gospodarczej w krajach WNP w latach 2000-2014}

W celu stworzenia syntetycznego miernika niezbędnego do analizy liczbowej wskaźniki transformacji EBOR zostały ujęte w formie średniej arytmetycznej. W poszczególnych latach liczba wskaźników uwzględnianych przy obliczaniu średniej wahała się, co wiązało się ze zmianami metodologii i kompleksowości analizowania obszarów problemowych. W latach 2000-2001 średnia arytmetyczna została policzona na podstawie ocen w ramach ośmiu kategorii: małej prywatyzacji, dużej prywatyzacji, restrukturyzacji przedsiębiorstw, liberalizacji cen, reform w zakresie handlu i rynku walutowego, polityki konkurencyjności, sektora bankowego i liberalizacji stóp procentowych oraz rynku papierów wartościowych i niebankowych instytucji finansowych. W latach 2002-2010 ocen było dziesięć za sprawą pojawienia się kategorii „infrastruktura”. W okresie 2011-2014 transformację monitorowano za pomocą sześciu wskaźników (z pominięciem kategorii „instytucje finansowe” oraz „infrastruktura”).

Do przeprowadzenia analizy korelacji między wolnością gospodarczą (mierzoną za pomocą Wskaźnika Wolności Gospodarczej) a postępami w transformacji gospodarek krajów WNP (ujmowanych jako średnia arytmetyczna wskaźników EBOR) posłużono się współczynnikiem korelacji liniowej Pearsona. O sile korelacji informuje wartość bezwzględna współczynnika. W niniejszym opracowaniu zostały przyjęte następujące przedziały liczbowe (Pułaska-Turyna 2008, s. 257):
$|0,0-0,2|$ - współzależność bardzo słaba;
$|0,2-0,4|$ - współzależność słaba;
$|0,4-0,6|$ - współzależność umiarkowana;
$|0,6-0,8|$ - współzależność silna;
$\mid 0,8$ - 1,0| - współzależność bardzo silna.

W przypadku ośmiu analizowanych krajów współczynnik korelacji liniowej był dodatni, co oznacza współzależność wprost proporcjonalną (tabela 4). Wraz ze wzrostem wartości Wskaźnika Wolności Gospodarczej zwiększała się średnia arytmetyczna wskaźników EBOR i odwrotnie - wraz ze spadkiem wartości Wskaźnika Wolności Gospodarczej średnia arytmetyczna wskaźników EBOR w danych krajach zmniejszała się. 
Tabela 4. Współzależność między wolnością gospodarczą a postępami w transformacji gospodarczej w krajach WNP w latach 2000-2014

\begin{tabular}{|l|c|l|l|}
\hline Kraj & Współczynnik korelacji & Kierunek korelacji & Siła korelacji \\
\hline Armenia & 0,602 & dodatni & silna \\
\hline Azerbejdżan & 0,867 & dodatni & bardzo silna \\
\hline Białoruś & 0,767 & dodatni & silna \\
\hline Kazachstan & 0,909 & dodatni & bardzo silna \\
\hline Kirgistan & 0,404 & dodatni & umiarkowana \\
\hline Mołdawia & $-0,519$ & ujemny & umiarkowana \\
\hline Rosja & 0,123 & dodatni & bardzo słaba \\
\hline Tadżykistan & 0,532 & dodatni & umiarkowana \\
\hline Ukraina & $-0,415$ & ujemny & umiarkowana \\
\hline Uzbekistan & 0,390 & dodatni & słaba \\
\hline
\end{tabular}

Źródło: obliczenia własne na podstawie danych Heritage Foundation i raportów EBOR.

Bardzo silną korelację dodatnią między analizowanymi zmiennymi w okresie 2000-2014 odnotowano w Kazachstanie $(0,909, \mathrm{p}<0,001)$ oraz Azerbejdżanie $(0,867, \mathrm{p}<0,001)$, a silna współzależność zachodziła na Białorusi $(0,767, \mathrm{p}=0,001)$ i w Armenii $(0,602, \mathrm{p}=0,018)$.

W Tadżykistanie i Kirgistanie występowała umiarkowana współzależność dodatnia między wolnością gospodarczą a postępami w transformacji. Współczynnik korelacji liniowej wynosił w przypadku tych krajów odpowiednio 0,532 $(\mathrm{p}=0,041)$ i $0,404(\mathrm{p}=0,135)$.

Zależność między wolnością gospodarczą a postępami w transformacji gospodarczej była ujemna (i zarazem umiarkowana) w przypadku dwóch krajów: Mołdawii $(-0,519, \mathrm{p}=0,047)$ i Ukrainy $(-0,415, \mathrm{p}=0,124)$.

\section{Analiza współzależności między wolnością gospodarczą i postępami w transformacji gospodarczej a rozwojem gospodarczym i społecznym w krajach WNP w latach 2000-2014}

Dodatkowym zagadnieniem wartym przeanalizowania jest współzależność między omówionymi wcześniej zmiennymi (wolnością gospodarczą oraz postępami w transformacji gospodarczej) a rozwojem gospodarczym i społecznym w krajach WNP. Na potrzeby badania rozwój gospodarczy został ujęty jako PKB per capita, 
a rozwój społeczny jako pryzmat Wskaźnika Rozwoju Społecznego (Human Development Index, HDI). Podobnie jak wcześniej, korelacja została obliczona za pomocą współczynnika korelacji liniowej Pearsona.

WNP to grupa krajów silnie zróżnicowanych pod względem rozwoju gospodarczego i społecznego. W 2000 r. najwyższą wartość wskaźnika PKB per capita wśród analizowanych państw zanotowano w Rosji (1 771,6 USD), a najniższą - w Tadżykistanie (138,4 USD). Mimo że do 2014 r. we wszystkich krajach WNP wskaźnik PKB per capita wyraźnie wzrósł, to wartości minimalne i maksymalne ponownie dotyczyły tych samych państw, a wartość PKB per capita $\mathrm{w}$ Rosji była ponad 12 razy wyższa niż w Tadżykistanie.

Bardzo silną korelację dodatnią w przypadku rozwoju gospodarczego i wolności gospodarczej w latach 2000-2014 odnotowano w Kazachstanie $(0,931$, $\mathrm{p}<0,001)$, Azerbejdżanie $(0,921, \mathrm{p}<0,001)$ oraz na Białorusi $(0,869, \mathrm{p}<0,001)$ (tabela 5a). Silna współzależność dodatnia dotyczyła Tadżykistanu oraz Kirgistanu. W przypadku Rosji współczynnik korelacji liniowej Pearsona wyniósł 0,015 $(\mathrm{p}=0,958)$, co świadczy o bardzo słabym skorelowaniu obu zmiennych i małej istotności związku. W przypadku Mołdawii i Ukrainy współzależność miała charakter ujemny.

Tabela 5. Współzależność między rozwojem gospodarczym a wolnością gospodarczą (a) oraz rozwojem gospodarczym a postępami w transformacji gospodarczej (b) w krajach WNP w latach $2000-2014$

\begin{tabular}{|l|c|c|}
\hline Kraj & $\mathrm{a}$ & $\mathrm{b}$ \\
\hline Armenia & 0,546 & 0,898 \\
\hline Azerbejdżan & 0,921 & 0,891 \\
\hline Białoruś & 0,869 & 0,945 \\
\hline Kazachstan & 0,931 & 0,913 \\
\hline Kirgistan & 0,751 & 0,798 \\
\hline Mołdawia & $-0,495$ & 0,932 \\
\hline Rosja & 0,015 & 0,942 \\
\hline Tadżykistan & 0,786 & 0,900 \\
\hline Ukraina & $-0,311$ & 0,938 \\
\hline Uzbekistan & 0,513 & 0,895 \\
\hline
\end{tabular}

Źródło: obliczenia własne na podstawie danych Banku Światowego, Heritage Foundation i raportów EBOR.

Analiza korelacji między rozwojem gospodarczym a postępami w transformacji gospodarczej wykazała, że we wszystkich analizowanych krajach w latach 2000-2014 była ona dodatnia i bardzo silna (tab. 5. b). 
Tabela 6. Współzależność między rozwojem społecznym a wolnością gospodarczą (c) oraz rozwojem społecznym a postępami w transformacji gospodarczej (d) w krajach WNP w latach 2000-2014

\begin{tabular}{|l|c|c|}
\hline Kraj & $\mathrm{c}$ & $\mathrm{d}$ \\
\hline Armenia & 0,654 & 0,931 \\
\hline Azerbejdżan & 0,942 & 0,847 \\
\hline Białoruś & 0,872 & 0,967 \\
\hline Kazachstan & 0,901 & 0,884 \\
\hline Kirgistan & 0,753 & 0,748 \\
\hline Mołdawia & $-0,420$ & 0,838 \\
\hline Rosja & 0,084 & 0,966 \\
\hline Tadżykistan & 0,865 & 0,828 \\
\hline Ukraina & $-0,177$ & 0,953 \\
\hline Uzbekistan & 0,656 & 0,850 \\
\hline
\end{tabular}

Źródło: obliczenia własne na UNDP, Heritage Foundation i raportów EBOR.

W latach 2000-2014 w krajach WNP zaszły wyraźne zmiany w poziomie rozwoju społecznego. Szczególny wzrost wartości wskaźnika HDI odnotowano w Azerbejdżanie (z 0,64 w 2000 r. do 0,76 w 2014 r.) oraz na Białorusi (z 0,68 w 2000 r. do 0,81 w 2014 r.) $)^{1}$. W 2014 r. najwyższe wartości HDI wystąpiły na Białorusi i w Rosji $(0,81)$, a najgorzej wypadł Tadżykistan $(0,65)$. Niewiele lepsza względem rozwoju społecznego była sytuacja w Kirgistanie $(0,66)$.

Współzależność między rozwojem społecznym mierzonym jako wskaźnik HDI a wolnością gospodarczą w ośmiu z dziesięciu badanych krajów miała charakter dodatni. We wszystkich krajach z wyjątkiem Rosji korelacja dodatnia była silna lub bardzo silna (tabela 6c). Korelacja ujemna ponownie zaszła w przypadku Mołdawii i Ukrainy. Współczynnik korelacji liniowej Pearsona obliczony na podstawie wskaźnika HDI oraz średniej wskaźników EBOR był dodatni dla wszystkich analizowanych państw (tabela 6d). W większości krajów współzależność ta została oceniona jako bardzo silna. Wyjątkiem był Kirgistan, w którym współczynnik wyniósł $0,748(\mathrm{p}=0,001)$.

\section{Podsumowanie}

Nie ulega wątpliwości, że zmiany wprowadzające gospodarkę wolnorynkową powinny iść $\mathrm{w}$ parze $\mathrm{z}$ poszerzaniem wolności gospodarczej, która, kształtując stosunki między podmiotami operującymi na rynku, jest jednym z głównych filarów

${ }^{1}$ Wskaźnik HDI może przyjmować wartości od 0 do 1 , a im jego wartość wyższa, tym wyższy poziom rozwoju społecznego. 
gospodarki rynkowej. Analiza przeprowadzona za pomocą wskaźnika korelacji liniowej Pearsona pozwoliła na stwierdzenie, że w ośmiu z dziesięciu omawianych krajów zaliczanych do Wspólnoty Niepodległych Państw współzależność między wolnością gospodarczą a postępami w transformacji była dodatnia. Oznacza to, że wraz ze wzrostem jednej zmiennej wzrastają wartości drugiej i na odwrót, czyli wraz ze spadkiem jednej zmiennej spadają wartości drugiej. W czterech spośród tych krajów korelacja dodatnia była silna lub bardzo silna.

Korelację ujemną w latach 2000-2014 odnotowano w dwóch krajach - w Mołdawii i na Ukrainie. Wynikało to głównie z tendencji wzrostowej wartości wskaźników transformacji (zmiany były zazwyczaj postępowe i rzadko dochodziło do cofnięcia reform) oraz dużych wahań Wskaźnika Wolności Gospodarczej w tych krajach. Pod względem wolności gospodarczej Mołdawia wypadła w 2014 r. gorzej niż w roku 2000, więc ciężko w tym przypadku mówić o trendzie dodatnim. Z kolei w przypadku Ukrainy, analizując wartości Wskaźnika Wolności Gospodarczej w latach 2000-2014, można wyróżnić trzy okresy: lata 2000-2005 charakteryzujące się tendencją rosnącą, lata 2006-2011, w których widoczny był coroczny spadek wartości oraz lata 2012-2014, w których po raz kolejny odnotowano sytuację rozwojową.

Wahania Wskaźnika Wolności Gospodarczej w Mołdawii i na Ukrainie wpłynęły także na ujemne korelacje między wolnością gospodarczą a rozwojem gospodarczym oraz wolnością gospodarczą a rozwojem społecznym w obu krajach. Podobnej przyczyny bardzo słabego skorelowania obu związków można także upatrywać w przypadku gospodarki rosyjskiej.

Przeprowadzona analiza pozwoliła na stwierdzenie, że w takich krajach jak Azerbejdżan, Białoruś, Kazachstan, Kirgistan i Tadżykistan występowały silne współzależności między wolnością gospodarczą a rozwojem gospodarczym i wolnością gospodarczą a rozwojem społecznym. We wszystkich krajach WNP w okresie 2000-2014 można mówić o wysokim i wprost proporcjonalnym skorelowaniu następujących związków: (1) postępów w transformacji gospodarczej i rozwoju gospodarczego oraz (2) postępów w transformacji i rozwoju społecznego.

\section{Bibliografia}

Balcerowicz L. (1997), Socjalizm, kapitalizm, transformacja. Szkice z przełomu epok, PWN, Warszawa.

Bałtowski M., Miszewski M. (2007), Transformacja gospodarcza w Polsce, Wydawnictwo Naukowe PWN, Warszawa.

Baza danych Banku Światowego, https://data.worldbank.org (data dostępu: 27 marca 2019).

CIS STAT, www.cisstat.com/rus/ciscountry1.htm (data dostępu: 20 grudnia 2018).

Elementarne zagadnienia ekonomii (2007), red. R. Milewski, Wydawnictwo Naukowe PWN, Warszawa. 
Gwartney J., Lawson R., Block W. (1996), Economic Freedom of the World: 1975-1995, The Fraser Institute, Vancouver.

Heritage Foundation, www.heritage.org/index (data dostępu: 20 grudnia 2018).

Lemieux P., Moreau A. (2018), What Are the Benefits of Economic Freedom?, Institut Économique Molinari, Paris-Bruxelles, www.institutmolinari.org/IMG/ pdf/note-liberte-economique_en.pdf (data dostępu: 27 marca 2019).

Maksimczuk A. (2013), Granice państwowe, relacje z sasiedztwem gospodarczym $i$ wschodnie pogranicze Polski $w$ dobie transformacji, integracji i globalizacji, t. 1, Wydawnictwo Uniwersytetu w Białymstoku, Białystok.

Nasilowski M. (1995), Transformacja systemowa w Polsce, Wydawnictwo Key Text, Warszawa.

Pawłowicz K. (1993), Prawo człowieka do swobodnej działalności gospodarczej [w:] Prawa człowieka w spoteczeństwie obywatelskim, red. A. Rzepliński, Warszawa. Pułaska-Turyna B. (2008), Statystyka dla ekonomistów, Wydawnictwo Difin, Warszawa. Raporty EBOR, Transition Report 2000 - Transition Report 2014, www.ebrd. com/transition-report (data dostępu: 20 listopada 2018).

Stanisławek J. (2010), Podstawy statystyki. Opis statystyczny, korelacja i regresja, rozklady zmiennej losowej, wnioskowanie statystyczne, Oficyna Wydawnicza Politechniki Warszawskiej, Warszawa.

The Former Soviet Union in Transition (1993), red. R.F. Kaufman, J.P. Hardt, Joint Economic Committee, Congress of the United States, New York.

Timeline of the EBRD's history, www.ebrd.com/cs/Satellite?c=Content\&cid=13 $95249805913 \& \mathrm{~d}=$ Default\&pagename=EBRD $\% 2 \mathrm{FContent} \% 2 \mathrm{FContentLayo}$ ut (data dostępu: 20 grudnia 2018).

UNDP, http://hdr.undp.org/en/data (data dostępu: 27 marca 2019).

\section{Streszczenie}

Wolność gospodarcza jest jednym z głównych elementów gospodarki rynkowej, warunkującym jej sprawne i efektywne funkcjonowanie. W wielu krajach, które na początku lat 90 . XX w. stanęły przed koniecznością transformacji gospodarki z socjalistycznej na wolnorynkową, wolność gospodarcza jest wciąż słabo rozwinięta. Celem niniejszego artykułu jest przeanalizowanie współzależności między wolnością gospodarczą a transformacją z gospodarki nakazowo-rozdzielczej na wolnorynkową krajów Wspólnoty Niepodległych Państw. Badanie, obejmujące lata 2000-2014, zostało przeprowadzone za pomocą współczynnika korelacji liniowej Pearsona. Dodatkowo przeanalizowano związki korelacyjne między omawianymi zmiennymi a rozwojem gospodarczym i społecznym.

Słowa kluczowe: transformacja gospodarcza, gospodarki transformujące się, wolność gospodarcza, Wspólnota Niepodległych Państw 


\section{Summary}

Economic freedom and economic transformation in the CIS countries in the years 2000-2014

Economic freedom is one of the main elements of the market economy, conditioning its efficient and effective functioning. In many countries which faced the necessity to transform their economy from socialist to a free market in the early $1990 \mathrm{~s}$, freedom is still poorly developed. The aim of this paper is to analyse the correlation between economic freedom and economic transformation in the CIS (Commonwealth of Independent States) countries in the years 2000-2014.

Keywords: economic transformation, transition economies, economic freedom, Commonwealth of Independent States

JEL: P20, O10 